\title{
Temporal and spatial correlation in chick production of willow grouse Lagopus lagopus in Sweden and Norway
}

Author(s): Maria Hörnell-Willebrand, Vidar Marcström, Rolf Brittas, and Tomas Willebrand

Source: Wildlife Biology, 12(4):347-355.

Published By: Nordic Board for Wildlife Research

DOI: http://dx.doi.org/10.2981/0909-6396(2006)12[347:TASCIC]2.0.CO;2

URL: http://www.bioone.org/doi/full/10.2981/0909-6396\%282006\%2912\%5B347\%3ATASCIC $\% 5 \mathrm{D} 2.0 . \mathrm{CO} \% 3 \mathrm{~B} 2$

BioOne (www.bioone.org) is a nonprofit, online aggregation of core research in the biological, ecological, and environmental sciences. BioOne provides a sustainable online platform for over 170 journals and books published by nonprofit societies, associations, museums, institutions, and presses.

Your use of this PDF, the BioOne Web site, and all posted and associated content indicates your acceptance of BioOne's Terms of Use, available at www.bioone.org/page/terms_of_use.

Usage of BioOne content is strictly limited to personal, educational, and non-commercial use. Commercial inquiries or rights and permissions requests should be directed to the individual publisher as copyright holder. 


\title{
ORIGINAL ARTICLES
}

\section{Temporal and spatial correlation in chick production of willow grouse Lagopus lagopus in Sweden and Norway}

\author{
Maria Hörnell-Willebrand, Vidar Marcström, Rolf Brittas \& Tomas Willebrand
}

Hörnell-Willebrand, M., Marcström, V., Brittas, R. \& Willebrand, T. 2006: Temporal and spatial correlation in the chick production of willow grouse Lagopus lagopus in Sweden and Norway. - Wildl. Biol. 2006: 347-355.

We analysed the spatial and temporal dynamics of chick production of willow grouse Lagopus lagopus in the Swedish and Norwegian mountain region using harvest data covering 24-38 years and line-transect counts covering 6-10 years from the period 1960-2003. Juvenile and adult grouse were counted in the bag of harvested willow grouse in late August and throughout September at six sites in Sweden and Norway. In addition, numbers of juvenile and adult willow grouse were obtained from line-transect counts at 21 sites in Sweden just before the hunting season started on 25 August. The juvenile:adult ratio from the harvest data, estimated as number of juveniles per two adults, showed similar long-term averages and distributions between all six sites. The results from the line-transect counts revealed an overall higher average and a greater range of production between sites. We suggest that the difference between estimates based on line-transect counts and harvest data are caused by hunter behaviour. Hunters did not sample the juvenile and adult grouse in proportion to what was present in the population, e.g., productivity estimates derived from harvest samples will underestimate the proportion of juveniles in autumn in most years. We suggest that it is the harvest process that acts to adjust the juvenile to old bird ratio in the harvest data to a similar distribution in different sites. We found little evidence of regular fluctuations/cycles in annual production of juveniles from either harvest data or line-transect data. We conclude that chick production in willow grouse appears to fluctuate more irregularly than was previously believed based on harvest data and can not be used as a potential forecasting tool in willow grouse management as suggested earlier. Spatial correlation was weak and investigating only a limited number of sites to predict the proportion of juveniles in autumn should not be considered as a management tool for large areas such as the state-owned land in Sweden. Line-transect counts are costly, but do provide a more accurate estimate of the proportion of juveniles in the fall population than is revealed by harvest data. A more detailed understanding of hunter behaviour is obviously needed for better interpretation of harvest data.

Key words: chick production, fluctuation pattern, spatial, temporal, willow grouse

Maria Hörnell-Willebrand, International Institute for Applied Systems Analysis (IIASA), A-2361 Laxenburg, Austria - e-mail: willebra@iiasa.ac.at Vidar Marcström, Department of Physiology and Developmental Biology, Norbyvägen 18A, SE-752 36 Uppsala, Sweden - e-mail: vidar.marcström@ebc.uи.se 
Rolf Brittas, The Swedish Association for Hunting and Wildlife Management, Krontallsvägen 10,SE-791 55 Falun, Sweden - e-mail: rolf.brittas@jagarefor bundet.se

Tomas Willebrand, Department of Animal Ecology, Swedish University of Agricultural Sciences, SE-901 83 Umeå, Sweden - e-mail:tomas.willebrand@szooek. slu.se

Corresponding author: Maria Hörnell-Willebrand

Received 13 December 2004, accepted 19 October 2005

Associate Editor: Kathy Martin

Willow grouse Lagopus lagopus populations in Sweden and Norway show large annual fluctuations in breeding success (Hagen 1952). Several earlier studies have found 3-4 year regular fluctuations in synchrony with microtine rodents (Hagen 1952, Myrberget 1982, Marcström \& Höglund 1980, Steen et al. 1988). Although not well studied, it is often assumed that the variation in breeding success is synchronous over large areas (Myrberget 1982, Lindström 1996 and references therein). One hypothesis to explain changes between years in the spring numbers of grouse is that spring numbers change in response to variations in breeding success the previous year (Bergerud 1970, Bergerud et al. 1985, Bergerud \& Butler 1987). Before Bergerud (1970) a relationship between spring numbers and prior breeding success was noted in red grouse L. l. scoticus (Jenkins et al. 1963, 1967) and rock ptarmigan L. mutus (Watson 1965). It has been suggested that chick production varies in pattern so regular that it could be a potential forecasting tool in willow grouse management in Sweden and Norway (Steen 1989 and references therein).

We use the term cyclicity as a pattern of periodic fluctuations in the size of the per capita chick production, with approximately constant time period, but possibly with variable amplitude (Turchin 2003). Many of the long-term data sets that are used in the analysis of cycles are based on harvest data from Scandinavia. In Sweden, time series analysis of such harvest data of grouse and mountain hare Lepus timidus have shown a 3-4 year periodic pattern which is correlated with the microtine rodent cycle (Hörnfeldt 1978, Small et al. 1993, Lindström et al. 1994, but see Newey 2005). A similar pattern was found for willow grouse and microtine rodents in the southern mountain range (Marcström \& Höglund 1980, Steen et al. 1988). Time series analysis is an efficient approach to identify short-term cycles and cross-correlations between areas, with or without time lags, after removing possible long-term trends (Royama 1992, Turchin 2003).

Large-scale spatial synchrony in population fluctua- tions have been investigated for many decades (Moran 1952, Pollard 1991, Hanski \& Woiwod 1993, Ranta et al. 1995a,b, Steen \& Erikstad 1996, Heino et al. 1997, Lindström 1996). In Scandinavia, besides harvest data, only the Finnish grouse censuses have produced longterm survey data to investigate periodicity and spatial synchrony of tetraonids (Lindén 1988). The results show that forest grouse populations tend to fluctuate in 6-7 year cycles with strong spatial correlation for up to 200 km (Lindström 1996, Ranta et al. 1997) except for willow grouse populations in northern Finland that do not follow this pattern (Lindén 1988) where spatial synchrony usually decreases rapidly with distance between populations (Ranta et al. 1995a).

Willow grouse are hunted with shotguns, principally over pointing dogs, and two thirds of all hunting takes place during the first 10 days of the hunting season in both Sweden and Norway (Willebrand 1996, Kastdalen 1992). Smith (1997) showed that brood break-up occurred during mid- to late September, and most of the willow grouse hunting thereby took place before brood breakup. Willow grouse harvest on state-owned land in Sweden is managed in subunits of $10-100 \mathrm{~km}^{2}$, and harvest rates have been estimated to be in the range of $5-20 \%$, but rates of up to $50 \%$ of the autumn population have been reported (Kastdalen 1992, Smith \& Willebrand 1999).

In this paper, we analyse the spatial and temporal dynamics of chick production of willow grouse in the Swedish mountain region, and in parts of Norway, using data on harvest and line-transect counts. We also compare the different distributions of chick production obtained in the two data sets. We investigate the extent of regular periodicity and spatial synchrony in the proportion of juveniles in the autumn population. The aim of our investigation is to evaluate the hypothesis that chick production shows regular cyclic fluctuations with a high degree of spatial synchrony. If true, this would make it possible to reduce the number of areas that need 




Figure 1. Location of study sites in Sweden (\# 1-24) and in Norway (\# 79, 89 and 99). Solid dots represent sites where harvest data on willow grouse were collected, and squares represent line-transect sites.

to be counted in any one year, and information on breeding success can still be included when planning harvest management.

\section{Methods}

We obtained the number of juvenile and adult willow grouse from autumn harvest data at the following six sites in Sweden (S) and Norway (N): \# 1) Lövhögen (S; 19621996), \# 13) Ammarnäs (S; 1960-1996), \# 15) Arjeplog (S; 1974-1997), \# 79) Hattfjelldal (N; 1967-2003), \# 89) Grane/Vefsn (N; 1967-2003) and \# 99) Östre Slidre (N; 1979-2003; Fig. 1). Grouse were aged on the basis of colouration and pattern of moult (Bergerud et al. 1963) by professional biologists. From the data we determined the proportion of young to adult birds in the shot samples, expressed as juvenile:adult ratio $=2 * \sum$ (juveniles)/ $\Sigma$ (adults). Wings were collected from the beginning of the hunting season (25 August in Sweden and 10 September in Norway) to the end of September. Harvest data and line-transect counts were collected in different areas, except for site 14 (line transect) and 15 (harvest data), where both harvest data and line-transect counts have been estimated since 1977 at the same site.
Line-transect counts of willow grouse were started in Sweden in 1994 in order to monitor population status and change. Densities were estimated by distance sampling (Buckland et al. 1993, Hörnell-Willebrand 2005) carried out on walked line transects with the aid of pointing dogs. The counts were performed by carefully recruited dog handlers who were trained and evaluated every year. The areas were chosen randomly and designed to cover all habitat types in the areas, with lines going from low to high elevations. Data were collected from 10 sites in Norrbotten (during 1994-2003, i.e. 10 years), two sites in Västerbotten (during 1998-2003, i. e. six years) and nine sites in Jämtland (during 19962003, i.e. eight years; all in Sweden; see Fig. 1). The number of lines and the total length traversed in the different sites ranged within 7-20 lines and 60-200 km, respectively. The group size, age composition and the perpendicular distance to the line was recorded for each observation. Most line transects were conducted in the first or second week of August, and there was no evidence that survival rates of juveniles would be substantially lower than those of adults during the 2-3 week period between the line-transect counts and the start of the hunting season. Data from radio-tagged willow grouse showed no significant differences between juvenile and adult survival from the beginning of August until the hunting season started. During this period, two deaths in 31 adults and three deaths in 28 juveniles were recorded (T. Willebrand \& A. Smith, unpubl. data). Juvenile:adult ratios were calculated for each site and year from the total number of juveniles and adults observed during the line-transect counts, including unsuccessful breeders.

The line-transect counts were done during the first two weeks of August when juveniles are easily distinguishable from adults, and $>90 \%$ of all observations of willow grouse were within $80 \mathrm{~m}$ of the transect line (M. Hörnell-Willebrand, unpubl. data). The numbers of juveniles and adults were estimated from the original data prior to estimating densities using the program DISTANCE (Thomas et al. 2003). Data were not used to calculate the juvenile:adult ratio if an area provided $<10$ encounters of willow grouse in a year, regardless if a single bird, a flock or a brood was encountered. In total, 500-1,100 willow grouse encounters were registered each year. The assumptions of the distance sampling methods were tested on radio-tagged willow grouse in Norway by Pedersen et al. (1999), who found that willow grouse, both broods and single birds, directly on the census line were detected with certainty. The probability of detecting grouse during the surveys declined with distance from the transect line, and large flocks were relatively easier to ob- 
serve with increasing distances from the transect line than single birds. This was only a problem in years with low densities and few observations and was also corrected for by excluding years with $<10$ encounters of willow grouse and by discarding all observations beyond $100 \mathrm{~m}$.

Time series analysis was used to analyse the cyclic pattern of juvenile: adult ratios in the harvest data. Autoregressive time series analysis (Box \& Jenkins 1976) is based on the fact that, if a time series has a regular periodic component, then there will be a strong positive auto-correlation between observations separated by the length of the period (the lag). The dominant period of a cycle was identified by finding the lag at which the auto-correlation function (ACF)

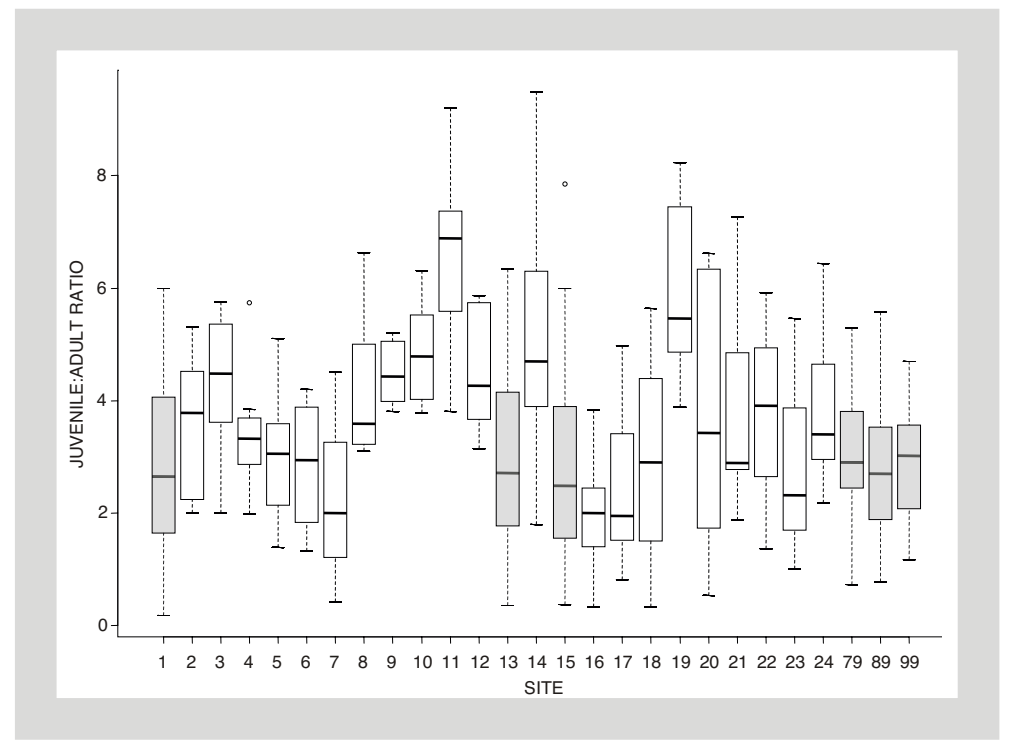

Figure 2. Box plot of juvenile:adult ratios calculated from sites \# 1-24 in Sweden and sites 79, 89 and 99 in Norway. Sites from which harvest data of willow grouse were obtained are shown in grey. Data for all other sites were obtained through line-transect counts of willow grouse. reached its first maximum. We used the Bartlett band $( \pm 2 / \sqrt{ } \mathrm{n})$ to estimate the significance of the correlation. To test for spatial correlation of juvenile:adult ratios between sites, we used Pearson's correlation coefficient. Four pairs of line-transect sites were adjacent to each other (\# 2 and 3, 4 and 5, 8 and 9, and 23 and 24) and they were pooled pairwise in the analysis to avoid pseudoreplication. All statistical treatment was run in R (R-Development-Core-Team 2004).

\section{Results}

The juvenile:adult ratios calculated from harvest data on willow grouse (from sites 1, 13, 15, 79, 89 and 99) resulted in almost identical means, but somewhat higher variance in the Swedish data $(\bar{x}=2.82-2.93, \mathrm{SD}=$ 1.43-1.79) than in the Norwegian data $(\bar{x}=2.79-3.03$, $\mathrm{SD}=0.93-1.20)$. The average juvenile:adult ratios calculated from line-transect data varied to a much larger extent $(\bar{x}=1.92-6.62, \mathrm{SD}=0.56-2.47)$. Of the 21 linetransect data sets, 16 produced substantially higher means, whereas five sets gave equal or lower means than the harvest data (Fig. 2).

The mean juvenile:adult ratio based on the line transect data was significantly higher than the mean of all harvest data $(\mathrm{t}=3.67, \mathrm{df}=22.13, \mathrm{P}<0.002)$, with a difference of more than one juveniles per two adults (3.99 compared to 2.88). For the two sites from which we obtained both harvest and line-transect data (\# 14 and 15), the mean juvenile:adult ratio estimated from line transects was almost twice the mean obtained from harvest data (5.12 vs 2.87 ), and the two series were poorly correlated, $\mathrm{r}=0.22(\mathrm{t}=1.06, \mathrm{df}=23, \mathrm{P}>0.25)$.

None of the time series of harvest data showed any significant trend over time using linear regression. We therefore chose not to detrend the data (Turchin 2003). The distributions of juvenile:adult ratios from harvest data were similar to each other (mean and SD), and did not warrant standardisation. Only site \# 1 showed strong evidence of a regular fluctuation in juvenile:adult ratios with a significantly positive lag in year 4 . One site in Norway (\# 79) also showed evidence of regular fluctuations with an almost significant 4-year period $(\mathrm{ACF}=0.323$, $2 / \sqrt{ } \mathrm{n}=0.329$ ) and a significantly negative correlation in year $2(\mathrm{ACF}=-0.413,2 / \sqrt{ } \mathrm{n}=-0.329)$, whereas site $\# 89$ (also in Norway) showed non-significant correlation in year 4 , but a significant negative correlation in year 2 $(\mathrm{ACF}=-0.473,2 / \sqrt{ } \mathrm{n}=-0.329)$. The two sites in northern Sweden (\# 23 and 24) and the remaining site in Norway (\# 99) showed no evidence of periodic fluctuations.

The juvenile:adult ratio was correlated without a time lag at sites \# 13 and 14 in Sweden $(r=0.66, P<0.001)$, at sites \# 89 and 79 in Norway and at site \# 1 in Sweden $(\mathrm{r}=0.77,0.53,0.46$, respectively, $\mathrm{P}<0.05)$. Sites \# 1 and 13 in Sweden and site \# 99 in Norway showed a significant negative cross-correlation with a lag of two years with each other, as did sites \# 79 and 98 in Norway. No other combination of sites in Sweden and Norway showed significant cross-correlation. The juvenile per two adults in the harvest data was apparently more in synchrony dur- 




Figure 3. Juvenile:adult ratio from time series based on harvest data of willow grouse from sites \# 1, 13 and 15 in Sweden and sites \# 79, 89 and 99 in Norway. After 1982, the time series appear to grow increasingly out of phase.

ing the 1970s (Fig. 3). We divided the longest time-series on harvest data (sites \# 1, 13, 79 and 89) into two parts of equal length and analysed each segment separately to detect a change with time. The only major change was that at site \# 1 the 4-year periodic fluctuation period disappeared in the first half, but remained in the second half of the time series.

The data from line transects covered too short a period to be used for time series analysis. There were no obvious common years for a population peak or low in the line-transect data as a whole, but at the county level there was poor production (0.4-2.8) at all sites in the northern county, i.e. Norrbotten, in 1998. In the southern county, i.e. Jämtland, there was no such common low or peak year. Instead there was an overall positive trend in juvenile:adult ratios using linear regression $\left(\mathrm{r}^{2}=0.20, \mathrm{t}=\right.$ $3.64, \mathrm{P}<0.001$ ) during the period 1996-2003 (all sites pooled).

There was a positive spatial correlation of juvenile: adult ratios between line-transect sites up to about 200 $\mathrm{km}$ apart although the correlation varied depending on which pair of sites were compared. The correlation did not increase for sites at distances shorter than $200 \mathrm{~km}$, and the three pairs of sites in the southern part of the mountain range that were adjacent to each other (\# 2 and 3, 4 and 5, and 8 and 9) did not show high correlation values $(r=0.59,0.20$ and -0.03 , respectively, $P=0.13$, 0.64 and 0.95 ), nor did the two sites adjacent to each other in the north of the mountain range (\# 23 and $24 ; r=-0.013, P=0.98$ ).

\section{Discussion}

It has earlier been known that the harvest data of willow grouse from Sweden and Norway produce almost identical long-term averages in juvenile: adult ratios (Steen 1989). The harvest data in our study had almost identical distributions, with a long-term average of about 2.8 juveniles per two adults. This would simplify the development of simulation models for harvest management (e.g. Willebrand \& Hörnell 2001) but appears to be a doubtful rigid biological feature of breeding success originating from different landscapes. The results from the line transect show a different pattern, with a wider distribution of values and obvious differences between sites. We suggest that the most important explanation for differences between the bag and line-transect data is similar behaviour of hunters in different parts of Scandinavia. Thus it is the harvest process in itself that acts to adjust the juvenile to old bird ratio in the harvest data to a similar distribution in different sites. This was also true for Norwegian harvest data compared to direct counts of willow grouse in the same area (Pedersen et al. 1999). Taylor (1999) also reported $>60 \%$ juveniles in the ground-based surveys whereas the harvest bag comprised 50\% juveniles in Alaska. Smith \& Willebrand (1999) found no difference in cause or proportions of deaths between ages and sexes of radio-tagged willow grouse during the period from 20 August until 30 November during a 4-year study in Sweden. Their unpublished data for the period (about 30 days) between line-transect counts and harvest did not show any differences between the survival rates of adults and juveniles. The same pattern was observed by Myrberget (1976) in Norway, who found that the proportion of juveniles in harvest data remained the same from early September over the autumn until winter. Thus, there is no evidence that the differences between harvest and line-transect data are caused by a higher mortality of juveniles than of adults. In line-transect counts, the whole brood with adults is usually counted, but during hunting only part of the brood is killed. We expect the individual probability of a chick to be killed at a hunter encounter to decrease with brood size, but the risk that 
adults are killed is expected to be less dependent on brood size. Our interviews with a number of hunting guides indicate that commonly one of the adults is shot when hunters encounter a brood. Furthermore, hunters seem to concentrate in habitats that have previously been known to have a high presence of broods, and they do not search each area with the same effort as in the linetransect counts (M. Hörnell-Willebrand, pers. obs.), a behaviour that would further equalise the distribution in harvest data.

Lindström et al. (1995) used the term clock-work for the population fluctuation of the Finnish woodland grouse, and Steen et al. (1988) suggested that chick production of willow grouse varied with such regularity that it could be used to predict good and bad years in grouse management. Our findings suggest that the regular periodicity in chick production is the exception rather than the rule in willow grouse, and there was little evidence of the 3-4 year regular fluctuations which are often assumed for chick production of tetraonids in Sweden and Norway (Hörnfeldt 1978, Myrberget 1972, Marcström \& Höglund 1980). Only one of six sites based on harvest data showed a significant positive correlation at any time lag (four years). There was only weak support of regular periodicity in the data from the three sites (\# 79, 89 and 99) in Norway. The strong autocorrelation at site \# 1 also vanished if only the first half of the time series was used in the analysis. This first half was characterised by 2-3 years of high values followed by a single crash year, whereas the second half of the series was characterised by several low values which were followed by a single peak. The data from the two northernmost sites (\# 23 and 24) in Sweden showed no evidence of regular fluctuations. Overall, the fluctuation patterns changed over time in all the time series based on harvest data. The data from the line transects also gave little support for a regular fluctuation of juveniles in autumn even though the series were shorter than those of the harvest data.

The juvenile:adult ratios in line-transect counts showed a spatial correlation between sites up to $200 \mathrm{~km}$ apart. The correlation coefficients at these distances are similar to spatial correlations of Finnish grouse populations (Lindström et al. 1996). We believe that the results from the line transects can sometimes be affected by area specific conditions since they are relatively small, and sites bordering each other did not particularly show a strong synchronous chick production. The two northernmost time series of harvest data in Sweden were correlated, but the two northernmost sites (\# 79 and 89) in Norway were more correlated with site \# 1 in the southern mountain range of Sweden. Judging from Figure 3 there ap- peared to be a period of more regular synchronous fluctuations, i.e. during approximately 1971-1982.

We believe that variation in annual production of willow grouse is to a large extent affected by external factors. Most likely, weather plays an important role in large-scale synchronisation (Lindström et al. 1996), but other factors such as food quality and predation are also known to be important. Of course none of these factors are independent, and they may interact in different ways. Weather seems to be the only likely candidate explanation for the long-distance correlations in the harvest data, but neither Hammarström (2001) nor Haakenstad (2003) found any evidence that weather was affecting the juvenile ratio in the harvest data. Brittas (1988) showed a positive relationship with spring weather, digestibility of food, abundance of microtine rodents and the breeding success of willow grouse at site \# 1 . The two years with the lowest breeding success were years with poor willow grouse nutrition and condition together with a decline in small mammal populations. Haakenstad (2003) emphasised the impact of predation for years with low numbers of microtine rodents as chick production was significantly lower in the years following the peak of microtine rodents.

Extremely bad weather during the first week after hatching has been shown to increase chick mortality (Marcström 1960, Höglund 1970, Marcström \& Höglund 1980, Erikstad \& Spidsø 1983). Slagsvold (1975) found a positive correlation between a high mean temperature in the middle of June and the breeding success of willow grouse. Myrberget et al. (1977) showed a similar relationship, with warm weather during the early chick period (the first week after hatching) having a positive effect on survival and growth rate of chicks. However, many studies have not found any correlation between chick survival and weather (Steen et al. 1988, Jenkins et al. 1963, Watson 1965, Bergerud 1970, Weeden \& Theberge 1972, Myrberget 1972, Myrberget 1974). It is difficult to evaluate weather data without an understanding of the potential mechanism between weather and breeding success. Climate changes have strong impacts on wildlife species at high elevations (Burton 1995, Jenik 1997, Inouyte et al. 2000), and higher temperatures have the potential to alter the amount of alpine and subalpine habitat and to increase alpine fragmentation because of rising subalpine tree lines (Roland et. al 2000, Martin 2001). Long-term monitoring programmes for alpine and subalpine wildlife, like the Swedish willow grouse census, will be important when even small increments in warming are shown to significantly impact habitat quantity and quality for breeding and migration in other Lagopus species (Martin 2001). 
We lack information on the fluctuations of voles Clethrionomys spp. and lemmings Lemmus lemmus in the areas we investigated, but our results do not contradict the hypothesis that predators are the main cause of annual variation in chick production. Voles mostly show regular fluctuations in the boreal forest of northern Scandinavia, with a 3-4 year periodicity, whereas lemming populations on the tundra have only a weak periodicity, despite large amplitudes and an almost chaotic fluctuation pattern (reviewed by Turchin 2003). In recent years, the regular cycles of voles have also tended to collapse (Hörnfeldt 2004, Strann et al. 2002), and we suggest that the absence of a 3-4 year periodicity in production of willow grouse is probably caused by irregular fluctuations of microtine rodents.

\section{Management implications}

In general, harvest data seem to underestimate the proportion of juveniles within populations across years in Norway and Sweden. But this is not necessarily true for all years; we speculate that the extent of bias depends on density of adults, proportion of successful pairs and brood size. In years with low density and moderate to high brood size, harvest data may well overestimate the true proportion of juveniles in the population (Pedersen et al. 1999; M. Hörnell-Willebrand, pers. obs.). Due to a general low encounter rate, hunters seem to kill a larger proportion in each brood but rarely find adults without broods as they are more separated from adults with broods at low than at high densities. Hörnell-Willebrand (2005) showed that the catchability of willow grouse increased as the population decreased.

However, harvest data on juvenile proportion can still be used to detect general patterns of production of juveniles, but they should not be used to compare different areas as these probably show larger differences than revealed by harvest data. A better understanding of how hunter behaviour is affected by different densities and breeding success would improve the interpretation of wing data. However, using direct counts in late summer or harvest data restricted to the period after brood breakup would also provide a less biased result.

The regular cyclic pattern of fluctuation in production of juveniles either does not seem to be as common as previously believed, or it has possibly deteriorated in later years. The fluctuations show a spatial correlation, but the variation is large both among sites and between years. Thus, only investigating a limited number of areas to predict the proportion of juveniles in autumn for large regions of the Scandinavian mountain range would introduce a large uncertainty in any management planning.
Line-transect counts require extra resources but can, mostly, be based on voluntary work. In addition to providing a more accurate estimate of the proportion of juveniles in the fall population, they also provide the information on density and spatial distribution which is needed to test predictions of the ecological effects of global climate change.

Acknowledgements - we thank Martin Håker and others at Statskog for providing the Norwegian harvest data, all enthusiastic and capable dog handlers who conducted the line-transect census in Sweden over the past 10 years, and the county boards administrating the line-transect census in Sweden. Funding was provided by the Swedish Environmental Protection Board, the Swedish Association for Hunting and Wildlife Management and Mountain MISTRA Program. We also thank Tuulikki Rooke, Scott Newey, Kjell Danell, Michael A. Shroeder, Christopher Heap and two anonymous referees that provided helpful comments on the manuscript.

\section{References}

Bergerud, A.T. 1970: Population dynamics of the willow ptarmigan Lagopus lagopus alleni L. in Newfoundland 1955 to 1965. - Oikos 21: 299-325.

Bergerud, A.T. \& Butler, H.E. 1987: Response to S.J. Hannon and F.C. Zwickel. - Auk 104: 345-347.

Bergerud, A.T., Mossop, D.H. \& Myrberget, S. 1985: A critique of the mechanics of annual changes in ptarmigan numbers. - Canadian Journal of Zoology 63: 2240-2248.

Bergerud, A.T., Peters, S.S. \& McGrath, R. 1963: Determining sex and age of willow ptarmigan in Newfoundland. - Journal of Wildlife Management 27: 700-711.

Box, G.E.P. \& Jenkins, G.M. 1976: Time series analysis: forecasting and control. - Holden Day Oakland, California, 575 pp.

Brittas, R. 1988: Nutrition and Reproduction of the Willow Grouse (Lagopus lagopus) in Central Sweden. - Ornis Scandinavica 19: 49-57.

Buckland, S.T., Anderson, D.R., Burnham, K.P. \& Laake, J. L. 1993: Distance Sampling: Estimating Abundance of Biological Populations. - Chapman and Hall, London, 446 pp.

Burton, J.F. 1995: Birds and climate change. - Helm, London, $376 \mathrm{pp}$.

Erikstad, K.E. \& Spids $\varnothing$, T.K. 1983: The effect of weather on survival, growth and feeding time in different sized willow grouse broods. - Ornis Scandinavica 14: 249-252.

Haakenstad, K.K. 2003: Ungfuglproduksjon av lirype Lagopus lagopus og fjellrype Lagopus mutus i Hattfjelldal, Grane og Vefsn - effekten av klima og predasjon. (In Norwegian with an English summary: Chick production in Willow Ptarmigan Lagopus lagopus and Rock Ptarmigan Lagopus mutus in Hattfjelldal, Grane and Vefsn - the effect of climate and predation). - Norges landbrukshögskole, Institutt for Biologi og Naturforvaltning, Ås, 42 pp. 
Hagen, Y. 1952: Rovfuglene of viltpleien. - Gyldendal, Norsk forlag, Oslo, 603 pp. (In Norwegian).

Hammarström, A. 2001: Long time fluctuations of three willow grouse populations in Sweden. - Department of Animal Ecology, Swedish University of Agricultural Sciences, Umeå, $28 \mathrm{pp}$.

Hanski, I. \& Woiwod, I. P. 1993: Mean-related stochasticity and population variability. - Oikos 67: 29-39.

Heino, M., Kaitala, V., Ranta, E. \& Lindström, J. 1997: Synchronous dynamics and rates of extinction in spatially structured populations. - Proceeding of the Royal Society of London B 264: 481-486.

Höglund, N. 1970: On the ecology of the Willow Grouse Lagopus lagopus in a mountainous area in Sweden. - In: Transactions of the VIIIth International Congress of Game Biology, Helsinki, pp. 118-120.

Hörnell-Willebrand, M. 2005: Temporal and spatial dynamics of willow grouse Lagopus lagopus. - Department of Animal Ecology, Swedish University of Agricultural Sciences, Umeå, 100 pp.

Hörnfeldt, B. 1978: Synchronous population fluctuations in voles, small game, owls and tularemia in northern Sweden. - Oecologia 32: 141-152.

Hörnfeldt, B. 2004: Long-term decline in numbers of cyclic voles in boreal Sweden: analysis and presentation of hypotheses. - Oikos 107: 376-392.

Inouyte, D.W., Barr, B., Armitage, K.B. \& Inouyte, B.D. 2000 Climate change is affecting altitudinal migrants and hibernating species. - In: Mooney H.M. (Ed.); Proceedings of the National Academy of Science. Vol. 97, pp. 1630-1633.

Jenik, J. 1997: The diversity of mountain life. - In: Messerli, B. \& Ives, D. (Eds.); Mountains of the world: a global priority. Parthenon Publishing Group London. pp. 199-231.

Jenkins, D., Watson, A. \& Miller, G. 1963: Population studies on Red Grouse (Lagopus lagopus Scoticus) in NorthEast Scotland. - Journal of Animal Ecology 32: 317-376.

Jenkins, D., Watson, A. \& Miller, G.R. 1967: Population fluctuations in the red grouse Lagopus lagopus scoticus. - Journal of Animal Ecology 36: 97-122.

Kastdalen, L. 1992: Skogshöns og jagt. - Report, Norges Bondelag, Norsk skogsbrukforening, Oslo, 46 pp. (In Norwegian).

Lindén, H. 1988: Latitudinal gradients in predator-prey interactions, cyclicity and synchronism in Voles and small game populations in Finland. - Oikos 52: 341-349.

Lindström, E.R., Andrén, H., Angelstam, P., Cederlund, G., Hoernfeldt, B., Jäderberg, L., Lemnell, P.A., Martinsson, B., Sköld, K. \& Swenson, J. E. 1994: Disease reveals the predator: sarcoptic mange, red fox predation, and prey populations. - Ecology 75: 1042-1049.

Lindström, J. 1996: Modeling Grouse Population Dynamics $\mathrm{PhD}$ thesis, University of Helsinki, Helsinki, $142 \mathrm{pp}$.

Lindström, J., Ranta, E., Kaitala, V. \& Lindén, H. 1995: The clockwork of Finnish Tetraonid population dynamics. Oikos 74: 185-197.

Lindström, J., Ranta, E. \& Lindén, H. 1996: Large-scale synchrony in the dynamics of Capercaillie, Black Grouse, and
Hazel Grouse populations in Finland. - Oikos 76: 221227.

Marcström, V. 1960: Studies on the physiological and ecological background to the reproduction of the Capercaillie Tetrao urogallus Lin. - Viltrevy 4: 311-342.

Marcström, V. \& Höglund, N. 1980: Factors affecting reproduction of Willow Grouse, Lagopus lagopus, in two highland areas of Sweden. - Swedish Wildlife Research 11: 285-314.

Martin, K. 2001: Wildlife communities in alpine and subalpine habitats. - In: Johnson, D.H. \& O’Neil, T.A. (Eds.); Wildlife habitat relationships in Oregon and Washington. Oregon University Press, Corvallis, pp. 239-260.

Moran, P.A.P. 1952: The Statistical Analysis of Game-Bird Records. - Journal of Animal Ecology 21: 154-158.

Myrberget, S. 1972: Fluctuations in a north Norwegian population of Willow Grouse. - Proceedings of the XVth International Ornithological Congress, the Hague, pp. 107-120.

Myrberget, S. 1974: Variations in the production of the Willow Grouse Lagopus lagopus (L.) in Norway, 1963-1972. - Ornis Scandinavica 5: 163-172.

Myrberget, S. 1976: Hunting, mortality, migration and age composition of Norwegian willow grouse Lagopus lagopus. - Norwegian Journal of Zoology 24: 47-52.

Myrberget, S. 1982: Bestandsvariasjoner hos lirype I Norge 1932-1971. - Meddelelser fra norsk Viltforskning 3: 1-31. (In Norwegian).

Myrberget, S., Erikstad, K.E. \& Spids $\varnothing$, T.K. 1977: Variations from year to year in growth rates of Willow Grouse chicks. - Astarte 10: 9-14.

Newey, S. 2005: Population fluctuations in mountain hares: a role for parasites? - Department of Animal Ecology, Swedish University of Agricultural Sciences, Umeå, 100 pp.

Pedersen, H.C., Steen, H., Kastdalen, L., Svendsen, W. \& Bröseth, H. 1999: Betydningen av jakt på lirypebestander. - Framdriftsrapport 1996-1998, Report No. 578, 43 pp. (In Norwegian).

Pollard, E. 1991: Synchrony of population fluctuations: the dominant influence of widespread factors on local butterfly populations. - Oikos 60: 7-10.

R-Development-Core-Team 2004: R: A language and environment for statistical computing. - R Foundation for Statistical Computing, Vienna.

Ranta, E., Kaitala, V., Lindström, J. \& Lindén, H. 1995a: Synchrony in population dynamics. - Proceedings of the Royal Society of London Series B Biological Sciences 262: 113118.

Ranta, E., Lindström, J. \& Helle, E. 1997: The spatial dimension in population fluctuations. - Science 278: 1621-1623.

Ranta, E., Lindström, J. \& Lindén, H. 1995b: Synchrony in tetraonid population dynamics. - Journal of Animal Ecology 64: 767-776.

Roland, J., Keyghobadi, N. \& Fownes, S. 2000: Alpine Parnassius butterfly dispersal: effects of landscape and population size. - Ecology 81: 1642-1653.

Royama, T. 1992: Analytical population dynamics. - Chapman \& Hall, London, 371 pp. 
Slagsvold, T. 1975: Production of young by the Willow Grouse, Lagopus lagopus L. in Norway in relation to temperature. Norwegian Journal of Zoology 23: 269-275.

Small, R.J., Marcström, V.\& Willebrand, T. 1993: Synchronous and nonsynchronous population fluctuations of some predators and their prey in Central Sweden. - Ecography 16: 360364.

Smith, A. \& Willebrand, T. 1999: Mortality causes and survival rates of hunted and unhunted Willow Grouse. - Journal of Wildlife Management 63: 722-730.

Smith, A.A. 1997: Movement, dispersal and survival patterns of Swedish willow grouse (Lagopus lagopus L.). - Doctoral thesis, University of Oxford, Oxford, $140 \mathrm{pp}$.

Steen, H. \& Erikstad, K.E. 1996: Sensitivity of Willow Grouse Lagopus lagopus population dynamics to variations in demographic parameters. - Wildlife Biology 2: 27-35.

Steen, J.B. 1989: Ryper. Rypeliv og rypejakt. - Gyldendal Norsk Forlag, Oslo, 367 pp. (In Norwegian).

Steen, J.B., Steen, H., Stenseth, N.C., Myrberget, S. \& Marcström, V. 1988: Microtine density and weather as a predictors of chick production in Willow Ptarmigan, Lagopus lagopus. - Oikos 51: 367-373.

Strann, K-B., Yoccoz, N.G. \& Ims, R.A. 2002: Is the heart of Fennoscandian rodent cycle still beating? A 14-year study of small mammals and Tengmalm's owls in northern Norway. - Ecography 25: 81-87.
Taylor, W.P. 1999: Game management unit 13 ptarmigan population studies. - Report No. Grant W-24-5, study 10.70, Alaska Department of Fish and Game, Division of Wildlife Conservation, Janeau, AK, 12 pp.

Thomas, L., Laake, J.L., Strindberg, S., Marques, F.F.C., Buckland, S.T., Borchers, D.L., Anderson, D.R., Burnham, K.P., Hedley, S.L., Pollard, J.H. \& Bishop, J.R.B. 2003: Distance 4.1 Release 2. - Research Unit for Wildlife Population Assessment, University of St. Andrews.

Turchin, P. 2003: Complex Population Dynamics: A Theoretical/Empirical Synthesis. - Princeton University Press, 486 pp.

Watson, A. 1965: A population study of ptarmigan (Lagopus mutus) in Scotland. - Journal of Animal Ecology 34: 135172.

Weeden, R.B. \& Theberge, J.B. 1972: The dynamic of a fluctuating population of rock ptarmigan in Alaska. - Proceedings of the International Ornithological Congress 15: 90-106.

Willebrand, T. 1996: Ripan och småviltjakten på statens mark ovanför odlingsgränsen och på renbetesfjällen. - 3.18. Naturvårdsverket (Swedish Environmental Protection Agency), Stockholm, 12 pp. (In Swedish).

Willebrand, T. \& Hörnell, M. 2001: Understanding the effects of harvesting willow ptarmigan Lagopus lagopus in Sweden. - Wildlife Biology 7: 205-212. 